\title{
WATERSHED TOPOGRAPHIC CHARACTERISTICS AND CAUSES ANALYSIS OF THE UPPER REACHES OF THE WEIHE RIVER
}

\author{
Zhiheng Liu ${ }^{1}$, Ling Han ${ }^{1,2, *}$, Tingting $\mathrm{Wu}^{1}$, Chengyan $\mathrm{Du}^{1}$, Ning Cao ${ }^{3}$ \\ ${ }^{1}$ School of Geological Engineering and Geomatics, Chang' an University, Xi'an 710064, China - (liuzhiheng, hanling, wutingting, \\ chengyandu)@chd.edu.cn \\ ${ }^{2}$ Shaanxi Key Laboratory of Land Consolidation, Xi'an 710064, China - hanling@chd.edu.cn \\ ${ }^{3}$ Land Satellite Remote Sensing Application Center, MNR, Beijing, 100048, China - caon@lasac.cn
}

Commission VI, WG VI/4

KEY WORDS: Watershed morphology, Gully density, Basin topography ratio, Roundness ratio, River longitudinal profile, Weihe River

\begin{abstract}
:
The morphology of watershed is the most intuitive information carrier to reflect regional tectonic activity, surface erosion and morphologic evolution. Active tectonic and fluvial system play a significant role in patterns and characters of regional morphology. Taking twenty-nine tributaries of the upper reaches of the Weihe River as the main study objects, four parameters, such as gully density (GD), basin topography ratio (BTR), roundness ratio (RR), river longitudinal profile fitting exponent (RLPFE), etc., were used to quantitatively analyse the topographic characteristics in this area. To reveal the main cause of the characteristics, the hypsometric integral (HI) were also applied in this area. The results showed that: (1) There is a positive linear function between basin topography ratio (BTR) and mean slope, and the mean values of four indexes in northern channels are smaller than southern channels; (2) The mean HI value is 0.44 , indicating that the main topographic characteristics of this area is in maturity, which is in the transitional period of adjustment of the deep erosion and uplift movement; (3) The main cause of this topographic changes is tectonic. These results are consistent with other geological background, and will enrich regional basin morphology research and tectonic activity evaluation, provide important basic data for regional disaster prediction and analysis of soil and water loss.
\end{abstract}

* Corresponding author: Ling Han (hanling@chd.edu.cn)

\section{INTRODUCTION}

As the typical loess watershed topography in China, the upper reaches of the Weihe River (URWR) are the result of active tectonics and water erosion (Rao et al., 2014; Cheng et al., 2018). Its formation, evolution, and relation to other regions have always been concerning in the previous documented studies (Rao et al., 2017; Shi et al., 2018). The uplift of the structures breaks the landforms developed in the past, and rivers adapt to the deformation by using erosion, indicating that the water system is widening or shrinking the size of the entire basin by eroding the bedrock on both sides. Under the tectonic and erosion, the regional landforms re-reach a relatively balanced steady state (Li, et al., 2012; Wang et al., 2014). They are the most important agents to change the topography (Wang et al., 2016; Shi et al., 2018), and can be used to analyse the characteristics and cause of the watershed topography. The topography not only records the information on the river erosion and tectonic evolution, but also is one of the important factors affecting erosion and sediment yield in watershed areas (Molina et al., 2008; Bywater-Reyes et al., 2017).

With the development of advanced GIS technology and higher resolution of remote sensing imageries, more and more researchers begin to study the mathematical statistics (Cheng et al., 2011), fractal (Brakenridge et al., 1988; David et al., 1988; Kusumayudha et al., 2000; Cai et al., 2014), and quantitative analysis (Shi et al., 2018; Zhang et al., 2019) on the topography of the loess plateau. These methods focused on the topographic relief, soil erosion, landforms evolution, watershed development, and climate changes in topographic. However, the systematic and comprehensive indicators to analyse erosion landforms characteristics and causes in loess plateau are still not explored. Under the interaction of climate, tectonic, and fluvial system, the geomorphological trend of the upper reaches of Weihe River still be worth considering.

In the experiments of this study, based on the SRTM1 data, the tributaries of Weihe River can be selected as the study objects and geomorphologic indexes used to analyse the landforms evolution and characteristics in URWR. In view of these points above, we focus on the main research questions about the topographic characteristics and causes of URWR.

\section{STUDY SITE AND DATA COLLECTIONS}

\subsection{Study site}

Weihe River is the largest tributary of Yellow River, China, originated in Weiyuan County, Dingxi City, Gansu Province and had elevation of $3495 \mathrm{~m}$ ( $\mathrm{Li}$ et al., 2012a). URWR located in the intersection between southwest margin of Ordos block, northern Qinling Orogenic Belt, and southern Liupanshan Mountain (Chen et al., 2018; Fan et al., 2018). The topographic characteristics is mainly controlled by active tectonics (Shi et al., 2018; Zhang et al., 2019). The maximum and minimum elevation of URWR are 3929 and $372 \mathrm{~m}$, respectively. The study area covered thick loess with an average thickness of 100 - $200 \mathrm{~m}$ (Fan et al., 2016). As shown in Figure 1a, two longitudinal profiles (AA' and BB') were extracted to analyse 
the relief based on SWATH tool (Pérez-Peña et al., 2017). As shown in Figure 1b, the relief changed with the topography. There is no particularly obvious terrain difference in the study area as a whole, but the relief decreases significantly with an elevation $\sim 400-800 \mathrm{~m}$ (Figure $1 \mathrm{~b}$ ) at the intersection of Ordos Block and Liupanshan Mountain (Figure 1a). The main channel of Weihe River flows from the west to the east, and is parallel to the Weihe fault (WF) (Figure 1a). However, the tributaries of the two sides are perpendicular to the main channel which the north channels are longer than the south channels. The asymmetric topography gives some evidence of the tectonics, but the main causes of the characteristics of the URWR still worth considering.

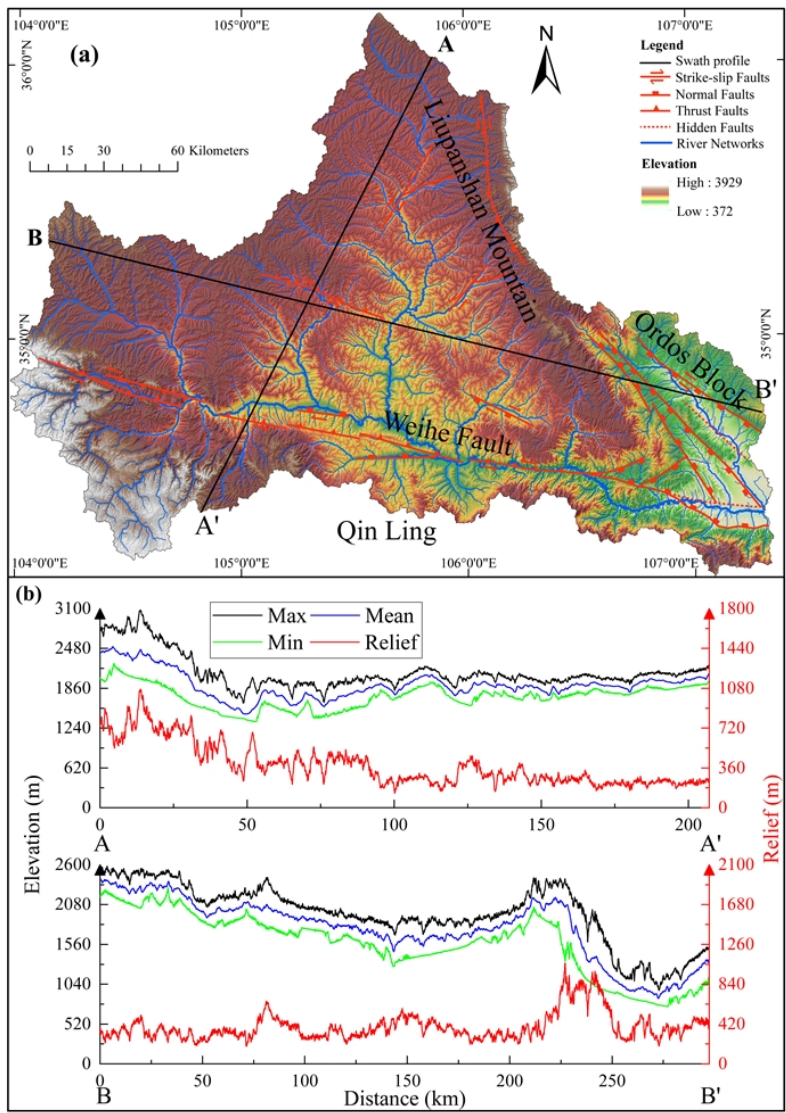

Figure 1. Topographic map of the upper reaches of the Weihe River, modified from (Li et al., 2012a; Chen Shi et al., 2018,

Shi et al., 2018). The SRTM1 data is available at https://earthexplorer.usgs.gov. The relief is extracted by using the SWATH tool (Pérez-Peña et al., 2017)

\subsection{Data collections}

Previous studies have shown that the DEM and remote sensing data can be used in landform evolution and soil erosion (Khan et al., 2012; Rao et al., 2017). The SRTM1 data is available at https://earthexplorer.usgs.gov, which provides 1 arc sec data with the grid resolution of $30 \mathrm{~m}$. Furthermore, the previous researchers have shown that the SRTM1 data is better than ASTER-GDEM to analyse fluvial landscape development in mountain terrains (Boulton and Stokes, 2018). Therefore, the STRM1 data were clipped and processed by hydrology tool in ArcGIS 10.2 software to obtain the final DEM data in this study area.

\section{METHODOLOGY}

Previous studies have shown that the hydrological analysis can provide some new evidence on the tectonic activities (Rao et al., 2017), prediction of the probability in extreme hydrological events (Fiorentino et al., 2007), and soil erosion (Jiang et al., 2017), etc. Therefore, some new indexes (Li et al., 2017) are proposed to analyse the landforms characteristics in this area.

\subsection{Gully density (GD)}

Gully density is an index representing gully length per unit area, and can reflect the surface fragmentation, the intensity of soil erosion (Jiang et al., 2017), and the change in vegetation cover and topography (Zhao et al., 2016). It can be calculated as follows:

$$
G D=\frac{L}{A}
$$

where $\quad L=$ the total length of basin gully $(\mathrm{km})$

$A=$ watershed areas $\left(\mathrm{km}^{2}\right)$

In this experiment, the gully can be replaced by surface runoff path. It is easy to extract the runoff path under the help of hydrology technology and DEM data.

\subsection{Basin topography ratio (BTR)}

This ratio is defined as the ratio of relative height difference between the highest and lowest points in the basin to the maximum horizontal distance parallel to the main river channel (Li et al., 2017). This index is related to the elevation difference uplifted by the active faults. The main formula is as follows:

$$
B T R=\frac{H_{\max }}{L_{\max }}
$$

where $H_{\max }=$ the relative height difference between the highest and lowest points $(\mathrm{km})$

$L_{\max }=$ the maximum horizontal distance parallel to the river channel $(\mathrm{km})$

\subsection{Roundness ratio (RR)}

Roundness ratio represents the shape of the watershed area, which is related to the asymmetric topography and bedrock lithologies ( $\mathrm{Li}$ et al., 2017). Previous studies have used the distribution of drainage basin asymmetry classes to analyse the shape of the basins ( $\mathrm{Li}$ et al., 2012a; Zhang et al., 2019). Their main results gave some evidence that the basin shape tends to be more circular with continued evolution (Zhang et al., 2019). Furthermore, the lower the landform development, the slower the topography of the basin, and the greater the RR values ( $\mathrm{Li}$ et al., 2017). Therefore, the shape of the basin can be used to investigate the characters of the watershed areas, and the calculation can be shown as follows:

$$
R R=\frac{A_{b}}{A_{c}}
$$

where $\quad A_{b}=$ the area of basin $\left(\mathrm{km}^{2}\right)$

$A_{c}=$ the area of a circle equal to that of a watershed perimeter $\left(\mathrm{km}^{2}\right)$ 


\subsection{River longitudinal profile fitting exponent (RLPFE)}

The river longitudinal profile can provide some information between local channel slope and upstream drainage area (Shi et al., 2018), and their topographic features changed with the time (Li et ai., 2017). River longitudinal profile fitting exponent (RLPFE) is the fitting exponent of the river longitudinal profile. Previous studies have shown that the closer this index is $\sim 1$, the closer the period of the topography is erosion and adjustment; while the RLPFE is $>1$, the topography is stable; and the RLPFE $<1$, the topography is in a period of deep erosion ( $\mathrm{Li}$ et al., 2017). After extracting the main channels, the RLPFE values can be drawn from the distance from stream outlet and relative elevation difference.

\section{RESULTS}

Under the help of ArcGIS 10.2 software and the hydrological tool, twenty-nine tributaries and sub-basins were extracted as shown in Figure 2. The length of these tributaries ranges from 12.8 to $260.6 \mathrm{~km}$ (Table 1 ), where the maximum length is Channel N3. The areas of the sub-basins in the north are larger than the south, with a range of $46.6 \sim 10720.7 \mathrm{~km}^{2}$ (Table 1) Based on the detailed ways in the Methodology, four indexes for each sub-basin were calculated, as shown in Table 1. As shown in Figure 3, the four indexes of each sub-basin were calculated and classed into 5 categories in ArcGIS.

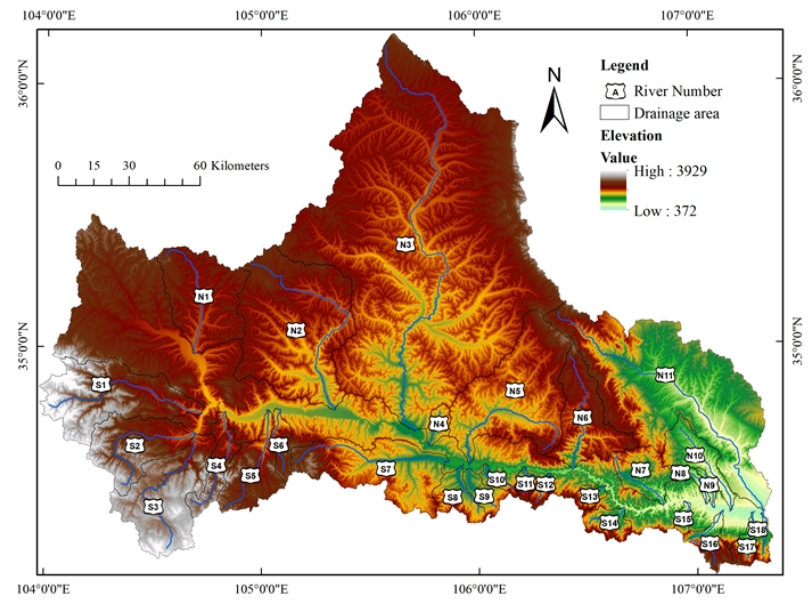

Figure 2. Distribution map of the main channels in URWR

Firstly, the GD values ranges from 0.213 to 0.356 , where the maximum and minimum values occurred in $\mathrm{N} 9$ and $\mathrm{S} 15$, respectively. Even though the northern rivers are longer than southern rivers (Figure 3a), the GD values of the northern rivers are smaller. From west to east, the GD values tends to be larger, especially in the N11, which located in the intersection of different blocks.

Secondly, there are not much difference on BTR values between different sub-basins (Figure 3b), with a range of $0.011-0.161$. The southeast rivers with smaller drainage areas have larger BTR values. And the larger the sub-basin areas, the smaller the BTR values. The mean BTR values in these sub-basins is 0.073 . As shown in Figure 3b, the largest BTR value located at Mazihe River (S13) in the southern margin, which covering an area of $104.6 \mathrm{~km}^{2}$. In these regions, the active faults tend to uplift by the Qinling (Figure 1). Therefore, the elevation difference is higher than north regions and the river length is shorter.

Thirdly, the RR values in the western margin are larger than the eastern margin. The RR values ranges from 0.205 to 0.610 , The maximum and minimum RR values located in the Sixiahe River (N4) and Qianhe River (N11), respectively. The mean RR values is 0.359 . The $R R$ values are $>0.3$ in the western region, showing that these regions are in the early stages of geomorphological development, while the eastern region are in the maturation stage of the landform development.

\begin{tabular}{|c|r|r|l|l|l|l|}
\hline No. & $\begin{array}{r}\text { River } \\
\text { length } \\
(\mathrm{km})\end{array}$ & $\begin{array}{r}\text { Basin } \\
\text { areas } \\
\left(\mathrm{km}^{2}\right)\end{array}$ & GD & BTR & RR & RLPFE \\
\hline N1 & 60.6 & 1160.3 & 0.250 & 0.042 & 0.461 & 1.890 \\
\hline N2 & 121.4 & 2481.3 & 0.253 & 0.021 & 0.420 & 1.272 \\
\hline N3 & 260.6 & 10720.7 & 0.257 & 0.011 & 0.347 & 1.076 \\
\hline N4 & 17.8 & 123.5 & 0.213 & 0.102 & 0.610 & 1.131 \\
\hline N5 & 82.8 & 1843.6 & 0.240 & 0.032 & 0.341 & 1.308 \\
\hline N6 & 66.1 & 852.0 & 0.235 & 0.040 & 0.245 & 0.928 \\
\hline N7 & 37.9 & 404.5 & 0.244 & 0.058 & 0.456 & 1.525 \\
\hline N8 & 24.3 & 92.8 & 0.278 & 0.072 & 0.263 & 1.401 \\
\hline N9 & 16.6 & 46.6 & 0.356 & 0.068 & 0.270 & 0.866 \\
\hline N10 & 49.0 & 426.7 & 0.249 & 0.042 & 0.271 & 1.329 \\
\hline N11 & 153.7 & 3500.6 & 0.268 & 0.018 & 0.205 & 2.367 \\
\hline S1 & 84.1 & 1364.2 & 0.231 & 0.047 & 0.267 & 1.553 \\
\hline S2 & 71.1 & 863.8 & 0.225 & 0.047 & 0.373 & 1.084 \\
\hline S3 & 79.9 & 1213.0 & 0.251 & 0.044 & 0.323 & 0.796 \\
\hline S4 & 55.8 & 361.0 & 0.265 & 0.056 & 0.265 & 1.261 \\
\hline S5 & 54.5 & 623.6 & 0.250 & 0.054 & 0.358 & 1.185 \\
\hline S6 & 33.2 & 182.8 & 0.312 & 0.078 & 0.318 & 1.326 \\
\hline S7 & 81.8 & 1255.5 & 0.248 & 0.033 & 0.271 & 2.226 \\
\hline S8 & 26.9 & 280.3 & 0.304 & 0.081 & 0.370 & 1.446 \\
\hline S9 & 26.1 & 182.2 & 0.238 & 0.084 & 0.392 & 2.357 \\
\hline S10 & 20.1 & 69.1 & 0.291 & 0.111 & 0.239 & 1.585 \\
\hline S11 & 18.5 & 83.9 & 0.303 & 0.129 & 0.478 & 1.423 \\
\hline S12 & 17.2 & 78.7 & 0.265 & 0.149 & 0.404 & 1.238 \\
\hline S13 & 15.3 & 104.6 & 0.257 & 0.161 & 0.515 & 1.594 \\
\hline S14 & 21.8 & 218.5 & 0.230 & 0.113 & 0.452 & 1.557 \\
\hline S15 & 12.8 & 69.5 & 0.213 & 0.153 & 0.491 & 1.847 \\
\hline S16 & 40.3 & 235.8 & 0.298 & 0.069 & 0.292 & 1.672 \\
\hline S17 & 26.5 & 161.3 & 0.266 & 0.101 & 0.419 & 2.001 \\
\hline S18 & 23.4 & 86.5 & 0.283 & 0.094 & 0.304 & 1.871 \\
\hline & & & & & & \\
\hline
\end{tabular}

Table 1. The main results in the study area

\section{where $\quad$ No. $=$ River number}

RLPFE $=$ river longitudinal profile fitting exponent,

$\mathrm{RR}=$ Roundness ratio,

$\mathrm{GD}=$ Basin topography ratio

$\mathrm{BTR}=$ Gully density, respectively.

Finally, the RLPFE values were obtained from the twenty-nine channels, ranging from $0.796 \sim 2.367$. All the river channels showed a trend of power function (Figure $3 \mathrm{~d}$ ) and the coefficient of determination $R^{2}$ are $>0.9$. The eastern rivers have larger RLPFE values than western rivers. The river with the largest length is Huluhe River (N3) and the RLPFE value is 1.076 (Figure 4), while the river with the smallest length is S15 and the RLPFE value is 1.847 . It is worth noting that Qianhe River (N11) is located at the margin of the study area, but the RLPFE value is the largest value (RLPFE $=2.367$ ) (Figure 4). 

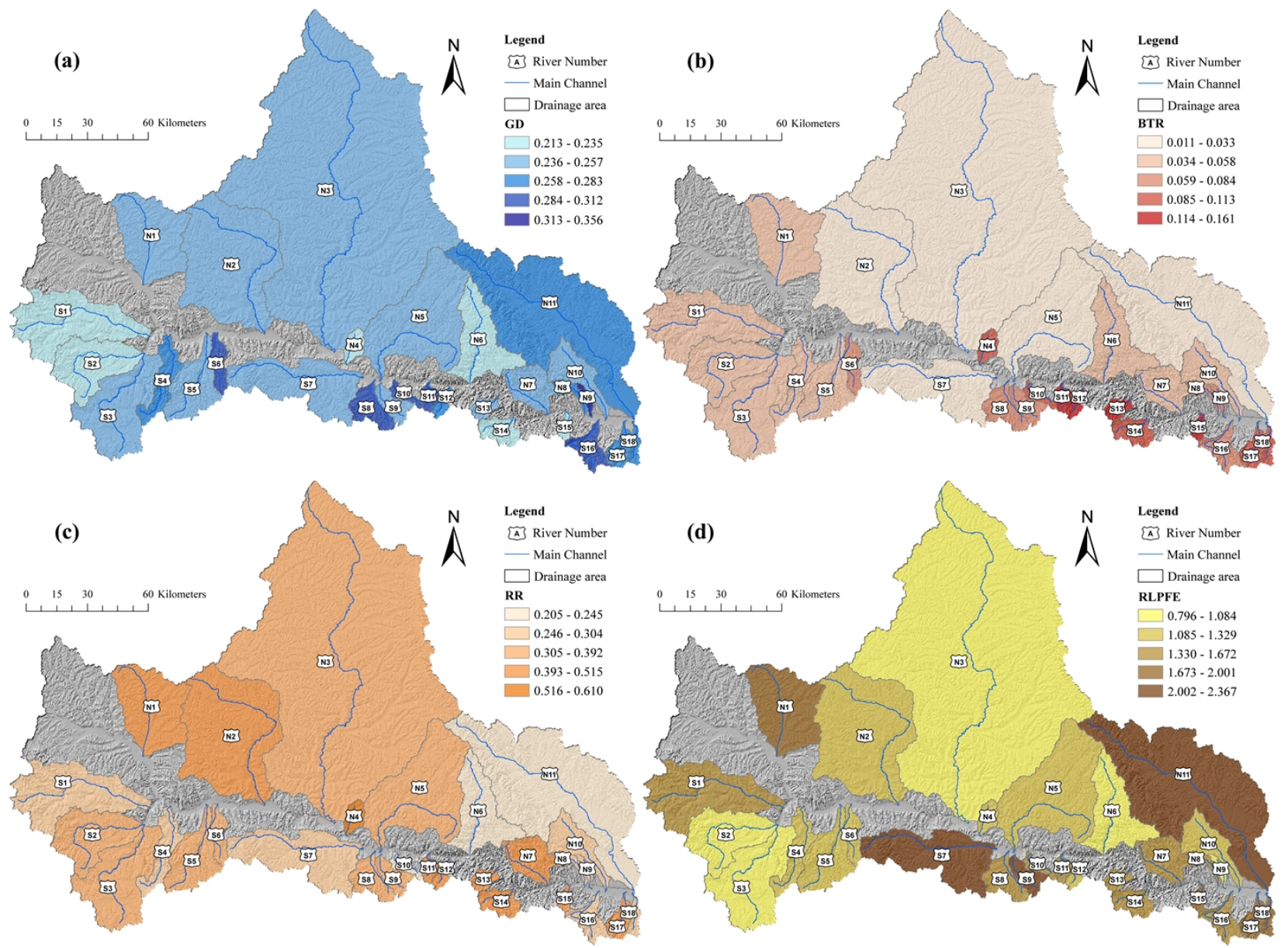

Figure 3. Distribution map of the upper reaches of the Weihe River
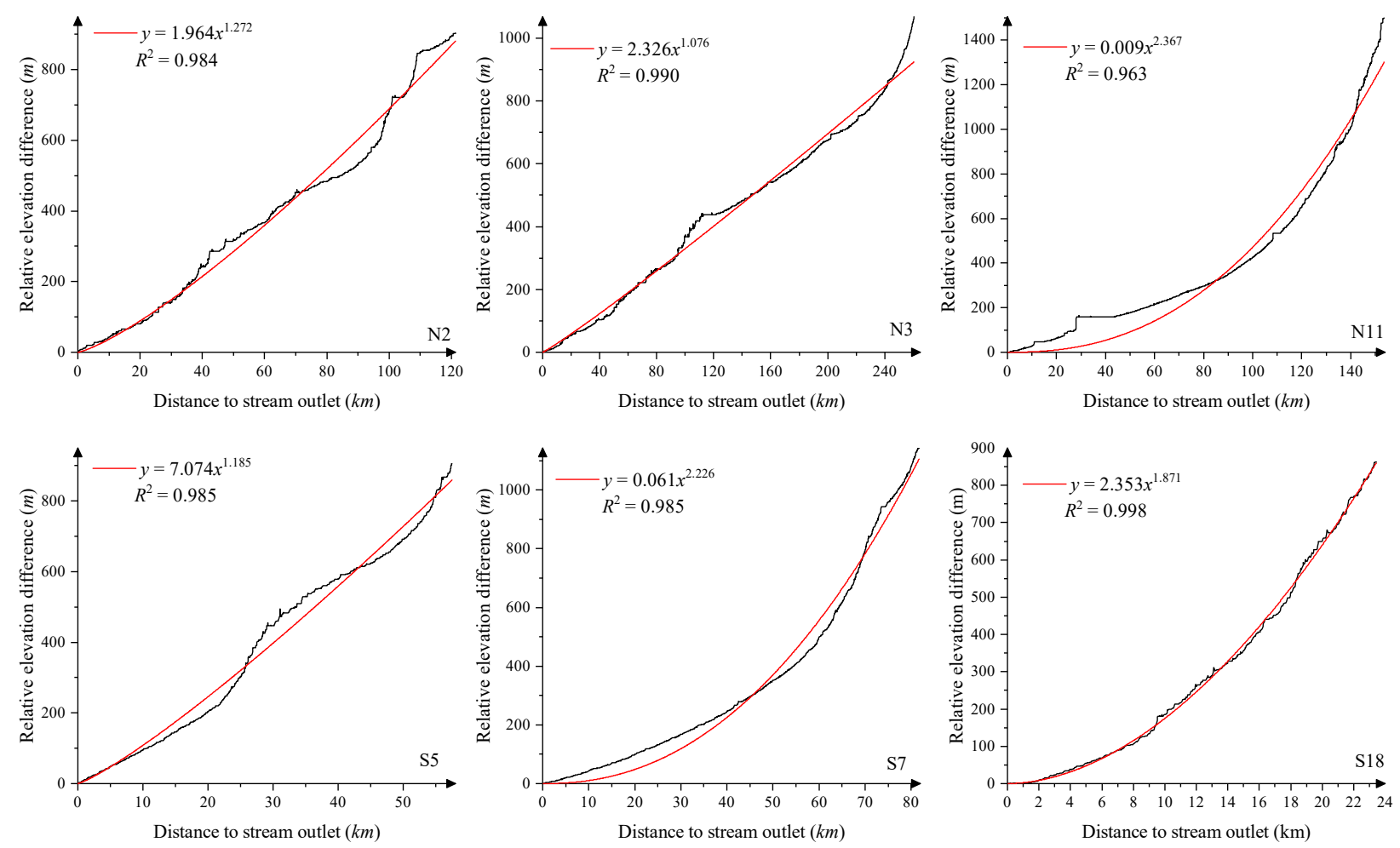

Figure 4. Sample maps of RLPFE in URWR 


\section{DISCUSSION}

The topographic characteristics represents the result of soil erosion and accumulation, and is a symbol of landform evolution. To compare the relationship between BTR and mean slope for sub-basins, a positive linear function was used and shown in Figure 6. The coefficient of determination $\left(R^{2}\right)$ is 0.50 , showing that the larger BTR values, the larger mean slope. As mentioned above, the largest BTR values $(\mathrm{BTR}=0.161)$ is located at River S13, which is in the southeast margin in URWR. In this area, with the eastward compression of the Tibetan Plateau ( $\mathrm{Li}$ et al., 2012a), the terrain difference and relief of the North Qinling area has been raised (Figure 1a), so the areas of the sub-basin in this area are relatively small (with an average area of $142.8 \mathrm{~km}^{2}$ from S8 to S18). Therefore, the BTR values in the southeast margin of this area is much higher than the other areas.

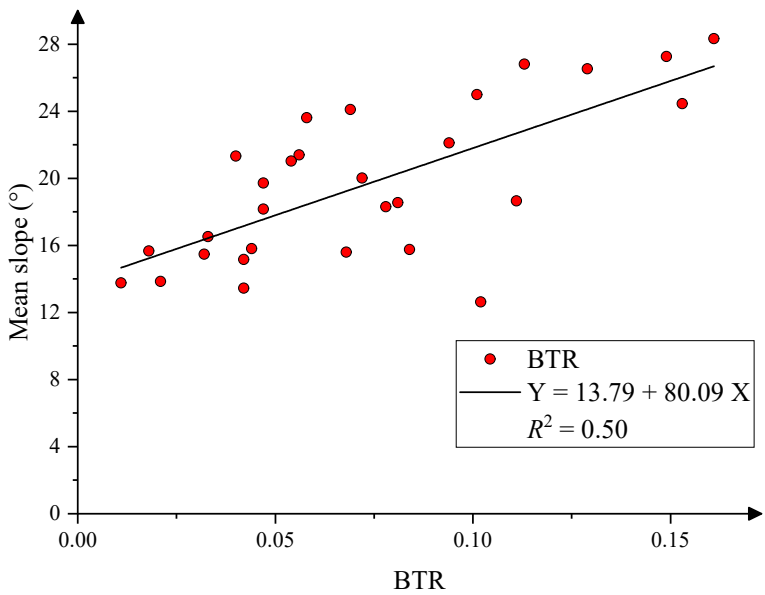

Figure 6. The relationship between the BTR values and mean slope for sub-basins

As for the northeast margin in this area, especially N11 (Qianhe River), four northwest trend faults located and had a higher tectonic activity (Figure 1) (Li et al., 2012a; Zhang et al., 2019). However, the BTR value is smaller than the southeast margin, with a BTR value of 0.018 (Table 1). This area is not only controlled by the compression of Tibetan Plateau, but also the strike-slip characteristics by Ordos Block (Fan et al., 2018), especially in the northeast of this area (Figure 1a). The Ordos block has reduced and weakened the compression from the Qinghai-Tibet Plateau, so BTR value is low even though its elevation is relatively high in this area. All of these have shown that the main topography of this area is mainly controlled by the tectonics, which is similar to the previous documented studies (Shi et al., 2018). Furthermore, based on the previous studies (Li et al., 2012a; Shi et al., 2018), there is no obviously change in climate and lithologies. Therefore, the main reason of the topographic in this area is tectonic.

Previous studies have shown that the tectonic activities can be evaluated by the hypsometric integral (HI) (Cheng et al., 2018; Zhang et a., 2019), and represents the elevation distribution in a basin ( $\mathrm{Li}$ et al., 2012a). It is a quantitative indicator to express the development stage of the landforms. Therefore, the HI values were used to analyse the ratio of the uneroded materials to the total materials. Followed by Strahler et al., (1952), the HI can be calculated as follows and the main results are shown in Table 2:

$$
H I=\frac{H_{\text {mean }}-H_{\min }}{H_{\text {max }}-H_{\text {min }}}
$$

where $\quad H_{\text {mean }}=$ the mean elevation in a sub-basin $(\mathrm{m})$

$H_{\max }=$ the maximum elevation in a sub-basin (m)

$H_{\min }=$ the minimum elevation in a sub-basin (m)

Followed by previous studies (Li et al., 2012b), when $\mathrm{HI}>0.50$, the river erosion is severe and the topography is in an unbalanced state, which is called infancy; When $0.40<\mathrm{HI} \leqslant$ 0.50 , the topography is called maturity; while $\mathrm{HI} \leqslant 0.40$, the topographic is in senility. The main results are shown in Table 2.

\begin{tabular}{|c|c|c|r|c|c|}
\hline No. & $H_{\operatorname{mean}}$ & $H_{\max }$ & $H_{\min }$ & HI & Period \\
\hline N1 & 2023 & 2541 & 1673 & 0.40 & Senility \\
\hline N2 & 1880 & 2518 & 1265 & 0.49 & Maturity \\
\hline N3 & 1869 & 2931 & 1135 & 0.41 & Maturity \\
\hline N4 & 1464 & 1828 & 1113 & 0.49 & Maturity \\
\hline N5 & 1770 & 2626 & 1073 & 0.45 & Maturity \\
\hline N6 & 1902 & 2653 & 912 & 0.57 & Infancy \\
\hline N7 & 1348 & 2200 & 693 & 0.43 & Maturity \\
\hline N8 & 1026 & 1765 & 620 & 0.35 & Senility \\
\hline N9 & 884 & 1128 & 598 & 0.54 & Infancy \\
\hline N10 & 1048 & 2056 & 583 & 0.32 & Senility \\
\hline N11 & 1301 & 2738 & 551 & 0.34 & Senility \\
\hline S1 & 2558 & 3929 & 1586 & 0.41 & Maturity \\
\hline S2 & 2422 & 3343 & 1637 & 0.46 & Maturity \\
\hline S3 & 2663 & 3492 & 1637 & 0.55 & Infancy \\
\hline S4 & 2299 & 3112 & 1497 & 0.50 & Maturity \\
\hline S5 & 2195 & 3096 & 1394 & 0.47 & Maturity \\
\hline S6 & 2046 & 2593 & 1363 & 0.56 & Infancy \\
\hline S7 & 1687 & 2712 & 1085 & 0.37 & Senility \\
\hline S8 & 1524 & 2189 & 1077 & 0.40 & Senility \\
\hline S9 & 1428 & 2179 & 1071 & 0.32 & Senility \\
\hline S10 & 1480 & 2223 & 1042 & 0.37 & Senility \\
\hline S11 & 1684 & 2377 & 993 & 0.50 & Maturity \\
\hline S12 & 1750 & 2557 & 945 & 0.50 & Maturity \\
\hline S13 & 1534 & 2448 & 850 & 0.32 & Senility \\
\hline S14 & 1562 & 2450 & 783 & 0.47 & Maturity \\
\hline S15 & 1145 & 1973 & 650 & 0.37 & Senility \\
\hline S16 & 1668 & 2777 & 588 & 0.49 & Maturity \\
\hline S17 & 1471 & 2691 & 560 & 0.43 & Maturity \\
\hline S18 & 1312 & 2205 & 551 & 0.46 & Maturity \\
\hline
\end{tabular}

Table 2. The HI values for each sub-basin

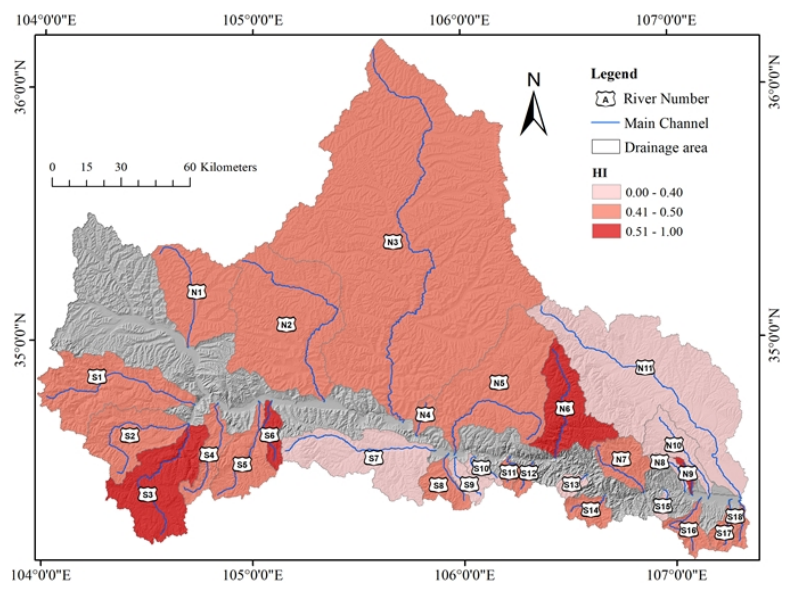

Figure 7. HI distribution map in this area 
In this Area, only four basins (N6, N9, S3, S6) are in infancy, ten basins are in senility (N1, N8, N10, N11, S7, S8, S9, S10, $\mathrm{S} 13, \mathrm{~S} 15)$, while the rest basins are in maturity (Table 2). The minimum $\mathrm{HI}$ value is 0.32 , where N10, S9 and S13 located, respectively. The mean $\mathrm{HI}$ value is 0.44 (Table 2 ), showing that the main topographic characteristics of this area is in maturity. The HI value of $\mathrm{N} 13$ is 0.34 , and the area is in senility. Comparing with other regions in URWR, the northeast margin, especially in basin N11, is more stable than western margin (Figure 7). These results are consistent with the previous studies (Li et al., 2012a) and the distribution of elevation (Figure 1a). However, due to the existence of many faults and the particularity of its geographical location (Figure 1a), the possibility of disaster induction in basin N11 is still very frequent.

\section{CONCLUSION}

Taking twenty-nine main tributaries of the upper reaches of the Weihe River as study objects, the topographic characteristics and causes were analysed by using four indexes (gully density, basin topography ratio, roundness ratio, and river longitudinal profile fitting exponent, respectively). Comparing to the other areas, the hypsometric integral (HI) were also used to describe the period for each sub-basin in this area. Some key findings were derived: (1) There is a positive linear function between basin topography ratio (BTR) and mean slope for each subbasin in this area; (2) The mean HI value is 0.44 , so the main topographic characteristics of this area is in maturity, which is in the transitional period of adjustment of the deep erosion and uplift movement; (3) The main cause of this topographic is tectonic. These results will enrich evaluation on tectonic activity, and provide data for regional disaster prediction, and soil and water loss.

\section{ACKNOWLEDGEMENTS}

This work was financially supported by application of SAR data in vegetation monitoring, under Grant [SKLGIE2017-Z-3-1]; the 1:50, 000 geological mapping in the loess covered region of the map sheets: Caobizhen (I48E008021), Liangting (I48E008022), Zhaoxian (I48E008023), Qianyang (I48E009021), Fengxiang (I48E009022), Yaojiagou (I48E009023) in Shaanxi Province, China, under Grant [DD20160060]. Thanks Pérez-Peña for providing the SWATH Profile Tool.

\section{REFERENCES}

Boulton, S.J., Stokes, M., 2018: Which DEM is best for analyzing fluvial landscape development in mountainous terrains? Geomorphology 310, 168-187. doi.org/10.1016/j.geomorph.2018.03.002.

Brakenridge G R., Thomas P A., Conkey L E., Schiferle J C., 1988: Fluvial sedimentation in response to postglacial uplift and environmental change, Missisquoi River, Vermont, Quaternary Research, 30(2), 190-203. doi.org/10.1016/00335894(88)90023-3.

Bywater-Reyes, S., Segura, C., Bladon, K.D., 2017: Geology and geomorphology control suspended sediment yield and modulate increases following timber harvest in temperate headwater streams. J. Hydrol. 548, 74-83. doi.org/10.1016/j.jhydrol.2017.03.048.
Cai L.Y., Tang G.A., Xiong L.Y., Kamila J. L., Xie T., Li Y.P., 2014: An analysis on fractal characteristics of typical landform patterns in northern Shaanxi loess plateau based on DEM, 34(3), 141-144. (In Chinese with English Abstract). doi.org/10.13691/j.cnki/stbctb.2014.03.027.

Chen, S., Fan, S., Wang, X., Wang, R., Liu, Y., Yang, L., Ning, X., Li, R., Li, S., 2018. Neotectonic movement in the southern margin of the Ordos Block inferred from the Qianhe River terraces near the north of the Qinghai-Tibet Plateau. Geol. J. 53, 274-281. doi.org/10.1002/gj.3111.

Cheng S.Y., Wang H.M., Li, Y.J., 2011: Geomorphology characteristics of the Wei River Basin and its formation reasons. Geography and Geo-Information Science, 27 (3), 45-49. (In Chinese with English abstract).

Cheng, Y., He, C., Rao, G., Yan, B., Lin, A., Hu, J., Yu, Y., Yao, Q., 2018. Geomorphological and structural characterization of the southern Weihe Graben, central China: Implications for fault segmentation. Tectonophysics 722, 11-24. doi.org/10.1016/j.tecto.2017.10.024.

David G T., Rafael L B., Ignacio R.T., 1988: The fractal nature of river networks. Water Resources Research, 24(8): 13171322.

Fan, S. H., Li, X. R., Wang, R., 2016: Bidding documents of "the 1:50,000 geological mapping in the loess - covered region with the map sheets: Caobizhen (I48E008021), Liangting (I48E008022), Zhaoxian(I48E008023), Qianyang (I48E009021), Feng xiang (I48E009022), and Yaojiagou (I48E009023) in Shaanxi Province of China. Chang'an University of China. (In Chinese).

Fan, S.-H., Chen, S.-E., Li, R., Li, S., 2018: Combined effects of the subductions of the Pacific Plate and Indian Plate in Central China in the Cenozoic: Recorded from the Wei River Basin. Geol. J. 53, 266-273. doi.org/10.1002/gj.3098.

Fiorentino, M., Manfreda, S., Iacobellis, V., 2007: Peak runoff contributing area as hydrological signature of the probability distribution of floods. Adv. Water Resour. 30, 2123-2134. doi.org/10.1016/j.advwatres.2006.11.017.

Jiang Y.C., Zhang W.T., Sheng J.D., 2017: Morphological characteristics of erosion gully and its driving factors in a typical small watershed in northern slope of Tianshan Mountains, Bulletin of Soil and Water Conservation, 37 (1), 304-307. doi.org/10.13961/j.cnki.stbctb.2017.01.053.

Khan, A., Ahmad, S., Khurshid, S., 2012: Geology and Geomorphology of the Manipur Valley Using Digitally Enhanced Satellite Image and SRTM DEM in the Eastern Himalaya, India. Int. J. Geosci. 03, 1010-1018. doi.org/10.4236/ijg.2012.325101.

Kusumayudha S.B., Zen M.T., Notosiswoyo S., Gautama R.S. 2000: Fractal analysis of the Oyo River, cave systems, and topography of the Gunungsewu karst area, central Java, Indonesia, Hydrogeology Journal, 8(3), 271-278. doi.org/10.1007/s100400050014.

Li C.R., Li F.Y., Ma J., Liu W., 2017: The study of watershed topography characteristics in the middle reaches of the Yellow 
River. Geography and Geo-information Science, 2017, 33(4), 107-112. (in Chinese with English abstract). doi.org/10.3969/j.issn.1672-0504.2017.04.018.

Li L.B., Xu G., Hu J.M., Yu X.B., Chen H., 2012a: Quantitative analysis of relative active tectonics of the upstream region of Weihe River based on DEM. Quaternary Sciences, 32 (5), 866-879. (in Chinese with English abstract). doi.org/10.3969/j.issn.1001-7410.2012.05.05.

Li L.B., Xu G., Hu J.M., Yu X.B., 2012b: An analysis of relative active tectonics based on DEM. Geology in China, 39 (3), 595-604. (in Chinese with English abstract).

Molina, A., Govers, G., Poesen, J., Van Hemelryck, H., De Bièvre, B., Vanacker, V., 2008: Environmental factors controlling spatial variation in sediment yield in a central Andean mountain area. Geomorphology 98, 176-186. doi.org/10.1016/j.geomorph.2006.12.025.

Pérez-Peña, J. V, Al-Awabdeh, M., Azañón, J.M., Galve, J.P., Booth-Rea, G., Notti, D., 2017: SwathProfiler and NProfiler: Two new ArcGIS Add-ins for the automatic extraction of swath and normalized river profiles. Comput. Geosci. 104, 135-150. doi.org/10.1016/j.cageo.2016.08.008.

Rao, G., Lin, A., Yan, B., Jia, D., Wu, X., 2014: Tectonic activity and structural features of active intracontinental normal faults in the Weihe Graben, central China. Tectonophysics 636, 270-285. doi.org/10.1016/j.tecto.2014.08.019.

Rao, G., Cheng, Y., Yu, Y., Yan, B., Lin, A., 2017: Tectonic characteristics of the Lishan Piedmont Fault in the SE Weihe Graben (central China), as revealed by the geomorphological and structural analyses. Geomorphology 282, 52-63. doi.org/10.1016/j.geomorph.2017.01.014.

Shi, X.H., Yang, Z., Dong, Y.P., Wang, S.D., He, D.F., Zhou, B., 2018: Longitudinal profile of the Upper Weihe River: Evidence for the late Cenozoic uplift of the northeastern Tibetan Plateau. Geol. J. 53, 364-378. doi.org/10.1002/gj.3195.

Strahler A H., 1952: Hypsometric (area-altitude) analysis of erosional topography. Geological Society of America Bulletin, 63.

Wang, Y.Z., Zhang, H.P., Zheng, D.W., Zheng, W.J., Zhang, Z.Q, Wang, W.T., Yu, J.X., 2014: Controls on decadal erosion rates in Qianlian Shan: Re-evaluation and new insights into landscape evolution in north-east Tibet. Geomorphology, 223, 117-128. doi.org/10.1016/j.geomorph.2014.07.002.

Wang, Y.Z., Zhang, H., Zheng, D., Pang, J., 2016: Streampower incision model and its implications: Discussion on the urgency of studying bedrock channel across the Tibetan Plateau. Quaternary Sciences, 36, 884-897. (in Chinese with English abstract). doi.org/10.11928/j.issn.1001-7410.2016.04.09.

Zhang, T.Y., Fan, S.H., Chen, S., Li, S., Lu, Y., 2019: Geomorphic evolution and neotectonics of the Qianhe River Basin on the southwest margin of the Ordos Block, North China. J. Asian Earth Sci. 176, 184-195. doi.org/10.1016/j.jseaes.2019.02.020.

Zhao, J., Vanmaercke, M., Chen, L., Govers, G., 2016: Vegetation cover and topography rather than human disturbance control gully density and sediment production on the Chinese

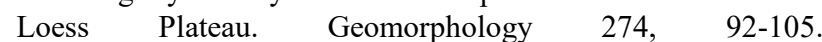
doi.org/10.1016/j.geomorph.2016.09.022. 